\title{
Infectious pancreatic necrosis virus in striped bass Morone saxatilis: experimental infection of fry and fingerlings
}

\author{
S. J. Wechsler ${ }^{1}$, C. L. Schultz ${ }^{2}$, P. E. McAllister ${ }^{3, *}$, E. B. May ${ }^{4}$ \& F. M. Hetrick ${ }^{2}$ \\ 'Florida Cooperative Fish and Wildlife Research Unit, 117 Newins-Ziegler, University of Florida, Gainesville, Florida 32611, \\ USA \\ ${ }^{2}$ Department of Microbiology, University of Maryland, College Park, Maryland 20742, USA \\ ${ }^{3}$ U.S. Fish and Wildlife Service, National Fish Health Research Laboratory, Box 700, Kearneysville, West-Virginia 25430, USA \\ ${ }^{4}$ Department of Pathology, University of Maryland, School of Medicine, Baltimore, Maryland 21201, USA
}

\begin{abstract}
Four strains of striped bass Morone saxatilis fry ( 1 to $20 \mathrm{~d}$ old) and fingerlings ( 26 to $180 \mathrm{~d}$ old), exposed to infectious pancreatic necrosis virus (IPNV), showed no clinical or histopathological signs of disease. This held true even when the fish were exposed to the virus and subjected to abrupt shifts in $\mathrm{pH}$ or temperature. Fish less than $20 \mathrm{~d}$ of age exposed to water-borne IPNV apparently developed only transitory infections and failed to produce IPNV-neutralizing activity. Fish $60 \mathrm{~d}$ or older inoculated with IPNV developed infections that persisted for at least 14 mo. Most IPNV-inoculated fish produced circulating virus-neutralizing activity even though virus could still be isolated from their tissues. We conclude that striped bass are resistant to IPNV-induced disease. However, in view of published information showing that striped bass can be naturally infected with IPNV, and our findings indicating that an IPNV carrier state can exist, we conclude that striped bass pose a potential threat to fish in IPNV-free waters. Striped bass should not be transplanted into such waters without first being checked to ensure that they are IPNV-free.
\end{abstract}

\section{INTRODUCTION}

Infectious pancreatic necrosis virus (IPNV) was isolated from moribund fry of striped bass Morone saxatilis being raised in a hatchery on the Chesapeake Bay, Maryland, USA (Schutz et al. 1984). The virus causes significant losses in hatchery-reared salmonids (Wolf et al. 1960). Recently there have been increased efforts to raise striped bass in hatcheries, therefore, we wanted to determine if IPNV is a pathogen for striped bass.

The specific objectives of this investigation were (1) to determine whether IPNV causes mortality in young striped bass, (2) to examine different strains of striped bass fry for variation in susceptibility to IPNV, and (3) to investigate the effects of environmental stress on mortality of striped bass challenged with IPNV.

\footnotetext{
- Addressee for reprint requests

(c) Inter-Research/Printed in F. R. Germany
}

\section{MATERIALS AND METHODS}

Cell culture and virus. Chinook salmon embryo (CHSE-214) cells were grown at $18^{\circ} \mathrm{C}$ in Eagle's minimal essential medium (MEM) containing $10 \%$ fetal bovine serum, $200 \mathrm{IU} \mathrm{ml} \mathrm{m}^{-1}$ penicillin (P) and $200 \mu \mathrm{g}$ $\mathrm{m}^{-1}$ streptomycin (S).

The striped bass IPNV isolate (Schutz et al. 1984) was passaged twice in CHSE-214 cells and aliquots of the virus were stored at $-70^{\circ} \mathrm{C}$. Prior to use, virus was diluted in phosphate-buffered saline (PBS, $\mathrm{pH} 7.2$, containing $\mathrm{P}$ and $\mathrm{S}$ ) to give the desired number of plaque forming units (pfu) per ml.

Fish. Four different strains of striped bass fry $(0$ to $5 \mathrm{~d}$ post-hatch) were obtained. The strains included: one from Florida (Richloam Fish Hatchery), one from Georgia (Richmond Hill State Fish Hatchery), and 2 from different populations in the Chesapeake Bay area (Chesapeake and Delaware [C \& D] Canali Nanticoke River) (Delmarva Ecological Laboratories, Inc., Mary- 
land). Fingerlings were obtained from Harrison Lake, Virginia, National Fish Hatchery.

Young fry were provided with brine shrimp Artemia salina nauplii as live food; fingerlings were fed a commercial trout and salmon ration. Fingerlings were kept in $15 \mathrm{l}$ tanks (50 fish per tank) receiving $4 \mathrm{l} \mathrm{min}^{-1}$ spring water at $21^{\circ} \mathrm{C}$, except where otherwise noted.

Virus challenge. For fry from Florida and Georgia, we placed 6 groups of 60 striped bass fry $(1,3,5,7,10$ and $15 \mathrm{~d}$ post-hatch) into $500 \mathrm{ml}$ tissue culture bottles (Corning Glass Works, Corning, New York) containing spring water $\left(19^{\circ} \mathrm{C}\right)$. Virus was added to 3 of the bottles to give $10^{6}$ pfu $\mathrm{ml}^{-1}$. A similar volume of virus-free PBS was added to the other 3 (control) bottles. After $6 \mathrm{~h}$, and daily thereafter, half of the water in each bottle was replaced, debris was removed, and newly hatched brine shrimp were added. All dead fish were removed and stored at $4{ }^{\circ} \mathrm{C}$ or $-20^{\circ} \mathrm{C}$ until assayed for virus.

Fry from the C \& D Canal and the Nanticoke River were divided into 6 groups of 30 fry $(1,5,10,15$ and $20 \mathrm{~d}$ post-hatch) in $200 \mathrm{ml}$ culture bottles containing Chesapeake Bay estuarine water $\left(18\right.$ to $\left.22^{\circ} \mathrm{C}\right)$. The fish were challenged as described above, except that $75 \%$ of the water was changed daily. Dead fish were stored at $4^{\circ} \mathrm{C}$ until they were assayed for virus (within $4 \mathrm{~d}$ ). At the end of $3 \mathrm{wk}$, most survivors were sacrificed and assayed for virus. A few survivors were bled and assayed for virus 6 mo after challenge.

Striped bass fingerlings ( $26 \mathrm{~d}$ old), held at 12 and $21{ }^{\circ} \mathrm{C}$, were given a $6 \mathrm{~h}$ exposure to virus in water containing $10^{4} \mathrm{pfu} \mathrm{ml}^{-1}$. During the challenge, water flow was stopped and aeration was provided. At each temperature, 4 tanks received virus, 4 tanks received an equal volume of virus-free diluent (PBS), and 4 served as treatment controls. The tanks were examined twice daily for $3 \mathrm{wk}$ and dead fish were collected and stored at $-20^{\circ} \mathrm{C}$ until assayed for virus.

For the challenge of striped bass $60,90,120,150$ and $180 \mathrm{~d}$ old, we anesthetized fish with tricaine methanesulfonate (MS-222) and administered $0.05 \mathrm{ml}$ of PBS containing $0,10^{3}, 10^{5}$, or $10^{6}$ pfu of virus by intraperitoneal (i.p.) injection. Treatment controls were anesthetized and returned to the tank. For $28 \mathrm{~d}$, dead fish were collected daily and stored at $-20^{\circ} \mathrm{C}$ until they were assayed for virus. At monthly intervals, survivors were anesthetized, bled, and assayed for virus.

Environmental stress. To test the effects of an abrupt shift in $\mathrm{pH}$, we placed $5 \mathrm{~d}$ old striped bass fry (C \& D strain) in $200 \mathrm{ml}$ bottles containing estuarine water and followed the virus challenge protocol previously described. The only difference for these fish was that at Day 5 following exposure to IPNV, we replaced $50 \%$ of the water ( $\mathrm{pH} 7.1$ ) with estuarine water that had been acidified to $\mathrm{pH} 6.3$ by the addition of sulfuric acid.
After $24 \mathrm{~h}$, the water was replaced with regular estuarine water.

To test the effect of an abrupt temperature shift, 24 6 mo old striped bass were allowed to acclimate for 2 wk to $12{ }^{\circ} \mathrm{C} ; 24$ other fish were maintained at $21^{\circ} \mathrm{C}$. All the fish were anesthetized and inoculated i.p. with $10^{6}$ pfu of virus. After $2 \mathrm{wk}$, half of the fish held at $12^{\circ} \mathrm{C}$ were transferred to $21^{\circ} \mathrm{C}$ and half of the fish held at $21{ }^{\circ} \mathrm{C}$ were transferred to $12{ }^{\circ} \mathrm{C}$. Fish were observed daily for mortalities. After 1 mo, 8 survivors from each group were bled and assayed for virus.

Processing of fish tissues for virus assay. Five to 10 fry (total weight less than $200 \mathrm{mg}$ ) were rinsed twice in PBS, blotted to remove excess liquid, and homogenized in $1 \mathrm{ml}$ of PBS by forcibly expelling the fry through a 20 gauge needle. The homogenate was filtered through a $0.45 \mu \mathrm{m}$ membrane filter. The fry filtrate was further diluted in PBS (3 serial 10-fold dilutions) and screened for virus using the simultaneous seeding assay described below.

Whole fish ( 0.5 to $5 \mathrm{~g}$ body weight), or internal organs from fish weighing more than $5 \mathrm{~g}$, were ground to a paste with a pestle and 90 mesh alundum (Fisher Scientific Co., Fairlawn, New Jersey) and mixed $1: 10$ $(\mathrm{wt} / \mathrm{v})$ in $\mathrm{PBS}$. The suspension was centrifuged (30 min, $\left.4^{\circ} \mathrm{C}, 1500 \times \mathrm{g}\right)$ to sediment debris. The supernatant liquid was further diluted (serial 10-fold dilutions) in PBS for virus assay using the plaque assay described below.

Virus assay. An aliquot $(0.05 \mathrm{ml})$ of each dilution of fry filtrate was added to 4 wells of a 96-well tissue culture plate. Then $0.1 \mathrm{ml}$ of CHSE-214 cells $\left(6 \times 10^{5}\right.$ cells $\mathrm{ml}^{-1}$ ) was added to each well. The plates were incubated at $18^{\circ} \mathrm{C}$ and examined daily for cytopathic effects (CPE). If no CPE were observed by the 5th day, the sample was blind-passaged. If no CPE were evident after 5 more $d$, the sample was considered to be negative for virus. Samples were recorded as being either positive or negative for virus.

Virus titers were determined using a virus plaque assay. Aliquots $(0.1 \mathrm{ml})$ of each sample dilution were inoculated onto duplicate drained CHSE monolayers and incubated for $1 \mathrm{~h}$ at $19^{\circ} \mathrm{C}$ to allow adsorption of the virus to the cells. The monolayers were overlaid with $1 \mathrm{ml}$ of tris-buffered MEM containing $1 \%$ agarose (SeaKem, FMC Corp., Rockland, Maine) and $2 \mathrm{ml}$ of medium without agarose. The plates were incubated at $18^{\circ} \mathrm{C}$ for $48 \mathrm{~h}$. The cell sheets were fixed with formalin and stained with $1 \%$ crystal violet in ethanol. Plaques were counted. Virus titers were expressed as pfu $\mathrm{ml}^{-1}$ or pfu $\mathrm{g}^{-1}$ of tissue.

Virus-neutralizing activity assay. Equal volumes of the striped bass isolate of IPNV $\left(1.6 \times 10^{3} \mathrm{pfu} \mathrm{ml} \mathrm{m}^{-1}\right)$ and sample (whole, virus-free fry filtrate or heated striped bass serum [diluted $1: 100$ ]) were mixed, incu- 
bated at $19^{\circ} \mathrm{C}$ for $1 \mathrm{~h}$, and assayed for residual infectivity by the virus plaque assay described above. Total virus was determined by assaying a mixture containing equal volumes of virus $\left(1.6 \times 10^{3} \mathrm{pfu} \mathrm{ml}^{-1}\right)$ and PBS. Samples that reduced total virus plaques by $50 \%$ or more were recorded as having virus-neutralizing activity.

Histological examination of virus-exposed fish. Striped bass less than $40 \mathrm{~d}$ old were fixed in a mixture of gluteraldehyde and formalin (1:4 parts) and embedded in hydroxyethyl methacrylate (HISTORESIN; LKBProdukter AB, Bromma, Sweden). Fingerlings were anesthetized and immersed in Bouin's fixative fluid. Tissues were embedded in paraffin (Luna 1968). All blocks were sectioned ( 4 to $6 \mu \mathrm{m}$ ), stained with hematoxylin, eosin and phloxine (Thompson 1966), and examined by light microscopy.

\section{RESULTS}

When 1 to $20 \mathrm{~d}$ old striped bass fry, from 4 striped bass strains, were challenged with IPNV by the waterborne route, resulting mortalities were not different from those of the unchallenged controls. The timing of the mortalities in different trials was unpredictable but, in any given trial, the daily pattern of mortalities in virus-challenged and control fish tended to coincide. Fig. 1 demonstrates this pattern of coinciding mortalities and illustrates IPNV recovery results typical for fish of the various strains exposed at different ages. When survivors were assayed for virus $3 \mathrm{wk}$ postchallenge, IPNV was only recovered from fry that had been challenged at $1 \mathrm{~d}$ post-hatch. Virus was not recovered from fish that survived to $6 \mathrm{mo}$ following water-borne challenge, and fish challenged by this

Table 1. Morone saxatilis. Cumulative mortalities in $26 \mathrm{~d}$ old striped bass challenged with water-borne infectious pancreatic necrosis virus (IPNV). Numbers in table show total mortality $(\%)$ during $20 \mathrm{~d}$ after IPNV exposure

\begin{tabular}{lcc}
\hline Treatment & $21{ }^{\circ} \mathrm{C}$ & Mortality \\
& 27 & $12{ }^{\circ} \mathrm{C}$ \\
\hline Virus $^{d}$ & 15 \\
Sham $^{\mathrm{b}}$ & 20 & 21 \\
Control $^{\mathrm{c}}$ & 32 & 20 \\
a Four tanks of 50 striped bass held at each tempera- \\
ture were challenged with a $6 \mathrm{~h}$ static exposure to $10^{4}$ \\
plaque-forming units per ml IPNV \\
${ }^{\circ}$ Four tanks with striped bass given a 6 h static expo- \\
sure to an equal volume of virus diluent exposure to an \\
equal volume of virus diluent (phosphate buffered \\
saline [PBS]) \\
'Four tanks with striped bass controls given a $6 \mathrm{~h}$ \\
static bath with no added virus or PBS \\
\hline
\end{tabular}

route never had detectable levels of IPNV-neutralizing activity.

Striped bass fingerlings, challenged at $26 \mathrm{~d}$ of age with water-borne IPNV, showed no increase in mortalities relative to those of the controls (Table 1 ). Further, virus was not recovered from any of these fish.

Striped bass fingerlings, challenged at 60 to $180 \mathrm{~d}$ of age with injected virus, also failed to show mortalities greater than those of the controls (Table 2). However, $72 \%$ of the fish that died during the first $28 \mathrm{~d}$ following inoculation with virus contained IPNV $\left(10^{2}\right.$ to $10^{7} \mathrm{pfu} \mathrm{g}^{-1}$ ) (Table 3 ).

Table 2. Morone saxatilis. Cumulative mortality in striped bass fingerlings after intraperitoneal inoculation of infectious pancreatic necrosis virus (IPNV). Groups of 50 striped bass were given intraperitoneal inoculations with the indicated number of plaque-forming units of IPNV. Numbers in table show number of fish that died in the $28 \mathrm{~d}$ following inoculation

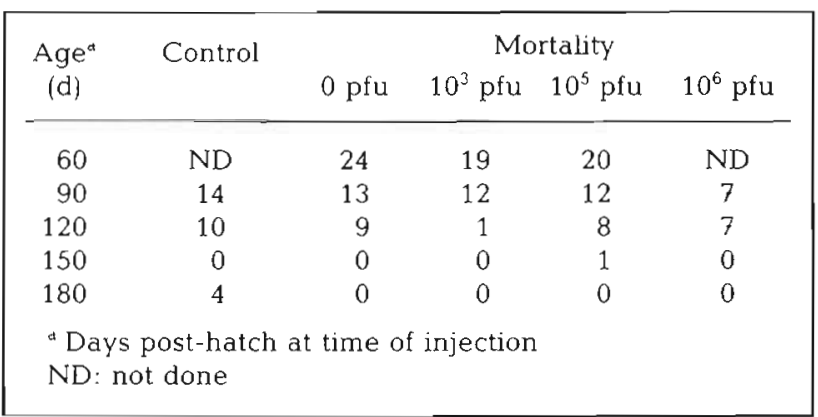

Table 3. Morone saxatilis. Range of virus titers recovered from striped bass fingerlings (held at $21^{\circ} \mathrm{C}$ ) that died during the first $28 \mathrm{~d}$ following intraperitoneal inoculation with indicated number of plaque forming units of infectious pancreatic necrosis virus (IPNV). Numbers in table show plaque-forming units (pfu) of IPNV per $g$ of tissue

\begin{tabular}{|c|c|c|c|c|c|}
\hline \multirow{2}{*}{$\begin{array}{l}\mathrm{Age}^{\mathrm{d}} \\
\text { (d) }\end{array}$} & \multirow[t]{2}{*}{ Control } & \multicolumn{4}{|c|}{ Virus recovered } \\
\hline & & 0 pfu & $10^{3} \mathrm{pfu}$ & $10^{5}$ pfu & $10^{6} \mathrm{pfu}$ \\
\hline 60 & ND & 0 & $10^{2}$ & $10^{3}-10^{5}$ & ND \\
\hline 90 & 0 & 0 & 0 & 0 & $10^{2}-10^{4}$ \\
\hline 120 & 0 & 0 & 0 & $10^{3}-10^{6}$ & $10^{5}-10^{7}$ \\
\hline 150 & $-b$ & - & - & $10^{5}$ & - \\
\hline 180 & 0 & - & - & - & - \\
\hline $\begin{array}{l}{ }^{2} \text { Day } \\
\text { Do } \\
\text { ND: }\end{array}$ & $\begin{array}{l}\text { post-hatc } \\
\text { sh died in } \\
\text { t done }\end{array}$ & $\begin{array}{l}\text { at time } \\
\text { his gro }\end{array}$ & f inocul & ion & \\
\hline
\end{tabular}

Virus was recovered from the majority of survivors from all age trials assayed 1 to 14 mo following virus inoculation (Table 4). Virus titers in survivors 1 mo after injection were similar to those from fish that had died during the first month following inoculation. Over a 14 mo period, levels of virus recovered from carriers gradually declined (Table 4 ). More than $75 \%$ of the 

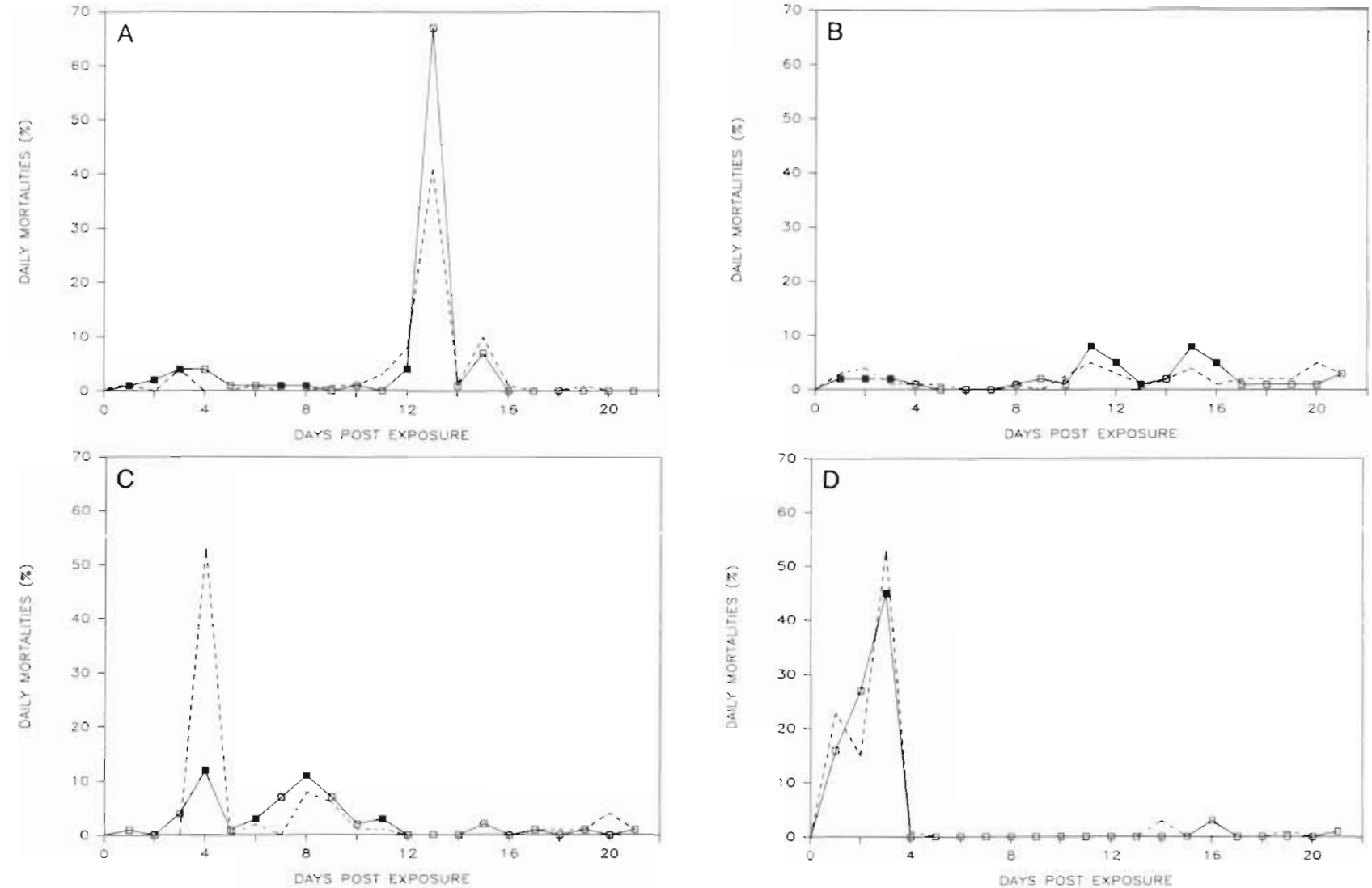

Fig. 1. Morone saxatilis. Pattern of daily mortalities in representative groups of striped bass fry (held at 18 to $22^{\circ} \mathrm{C}$ ) challenged with infectious pancreatic necrosis virus at $0(---)$ or $10^{6}$ plaque forming units per milliliter ( $\left.\square---\square\right)$. Virus was recovered only from fish indicated ( $)$. Fry (Chesapeake and Delaware [MD] strain) challenged at (A) $1 \mathrm{~d}$, and (B) $5 \mathrm{~d}$ post-hatch. Nanticoke River (MD) strain fry challenged at (C) $15 \mathrm{~d}$ and (D) $20 \mathrm{~d}$ post-hatch

virus-carrier fish tested showed IPNV-neutralizing activity in their sera. All IPNV-inoculated fish that tested negative for virus had circulating IPNV-neutralizing antibodies.

Histological examination of longitudinal sections of fry, and cross-sections taken through the pharyngeal, anterior kidney, and posterior kidney regions of fingerlings at 0 to 4 mo post-inoculation revealed no lesions indicative of viral infection. Examination of dissected organs from fish at 6 to 12 mo post-exposure also revealed no significant lesions.

Virus-challenged striped bass that were subjected to an abrupt drop in $\mathrm{pH}$ suffered mortalities no different from those of similarly challenged controls not experiencing the $\mathrm{pH}$ change. Mortalities were 40 and $41 \%$, respectively. Also, IPNV-inoculated fish that underwent an abrupt temperature shift did not show increased mortalities over similarly challenged controls not subjected to the temperature change. No mortalities occurred in either group. In addition, the mean virus titers recovered from infected fish sacrificed $2 \mathrm{wk}$ after the temperature shift were not significantly different $(p<0.01)$ from those not subjected to a change in temperature (Table 5).
Table 4. Morone saxatilis. Range of titers of infectious pancreatic necrosis virus (IPNV) recovered from all surviving virus inoculated striped bass fingerlings. Striped bass, held at $21^{\circ} \mathrm{C}$, received an intraperitoneal inoculation of the indicated pfu of IPNV Numbers in table show plaque forming units (pfu) of IPNV per gram of tissue from sacrificed fingerlings

\begin{tabular}{|c|c|c|c|}
\hline \multirow[t]{2}{*}{ Months } & \multicolumn{3}{|c|}{ Virus recovered } \\
\hline & $10^{3} \mathrm{pfu}$ & $10^{5} \mathrm{pfu}$ & $10^{6} \mathrm{pfu}$ \\
\hline 1 & 0 & $10^{3}-10^{4}$ & $10^{3}-10^{6}$ \\
\hline 2 & $10^{2}$ & $10^{2}-10^{4}$ & $10^{3}-10^{6}$ \\
\hline 3 & $10^{3}$ & $10^{4}$ & $10^{3}-10^{4}$ \\
\hline 4 & 0 & $10^{3}-10^{4}$ & $10^{3}-10^{4}$ \\
\hline 6 & $10^{1}-10^{2}$ & $0-10^{2}$ & $0-10^{3}$ \\
\hline 12 & $0-10^{1}$ & $0-10^{2}$ & $0-10^{1}$ \\
\hline 14 & ND & ND & $0-10^{2}$ \\
\hline \multicolumn{4}{|c|}{$\begin{array}{l}\text { "Mo after inoculation with virus } \\
\text { ND: not done }\end{array}$} \\
\hline
\end{tabular}

\section{DISCUSSION}

Mortalities in fry of different ages, representing 4 different strains of striped bass, were no different in fish challenged with water-borne IPNV than in those not exposed to the virus. These results indicate that 
Table 5. Morone saxatilis. Virus titers of striped bass fingerlings 1 mo after inoculation with $10^{6}$ plaque forming units (pfu) of infectious pancreatic necrosis virus (IPNV) and $2 \mathrm{wk}$ following the indicated change in water temperature. Numbers in table show plu of IPNV per gram tissue of sacrificed individual fish

\begin{tabular}{|c|c|c|c|c|}
\hline & \multicolumn{4}{|c|}{ Temperature } \\
\hline & $21^{\circ} \mathrm{C}$ & $12^{\circ} \mathrm{C}$ & $21 \rightarrow 12^{\circ} \mathrm{C}$ & $12 \rightarrow 21^{\circ} \mathrm{C}$ \\
\hline & $2.7 \times 10^{4}$ & $9.7 \times 10^{4}$ & $2.3 \times 10^{5}$ & $1.2 \times 10^{5}$ \\
\hline & $2.9 \times 10^{4}$ & $2.9 \times 10^{4}$ & $4.9 \times 10^{3}$ & $2.6 \times 10^{4}$ \\
\hline & $3.9 \times 10^{4}$ & $4.5 \times 10^{4}$ & $1.1 \times 10^{6}$ & $3.3 \times 10^{4}$ \\
\hline & $3.0 \times 10^{4}$ & $1.4 \times 10^{4}$ & $2.2 \times 10^{5}$ & 0 \\
\hline & 0 & $3.2 \times 10^{4}$ & $1.9 \times 10^{4}$ & $8.2 \times 10^{3}$ \\
\hline & $7.2 \times 10^{4}$ & $2.0 \times 10^{6}$ & $1.9 \times 10^{4}$ & $9.2 \times 10^{4}$ \\
\hline & 0 & $5.0 \times 10^{6}$ & $2.8 \times 10^{4}$ & $8.0 \times 10^{3}$ \\
\hline & $1.2 \times 10^{5}$ & $6.4 \times 10^{5}$ & $4.8 \times 10^{3}$ & $2.1 \times 10^{4}$ \\
\hline Mean ${ }^{d}$ & $4.0 \times 10^{4}$ & $9.8 \times 10^{5}$ & $2.0 \times 10^{5}$ & $3.9 \times 10^{4}$ \\
\hline $\mathrm{SD}^{\mathrm{c}}$ & 4.0 & 1.7 & 3.6 & 4.4 \\
\hline $\begin{array}{l}{ }^{a} \text { Group } \\
(p<0.01\end{array}$ & $\begin{array}{l}\text { means } \\
\text { analysis }\end{array}$ & $\begin{array}{l}\text { еге not } \\
\text { variance) }\end{array}$ & significantly & different \\
\hline
\end{tabular}

striped bass are not particularly susceptible to IPNVinduced disease. As mentioned earlier, the timing of mortalities occurring in IPNV-challenged and control fish always coincided within trials but predictions as to when the mortalities would occur in a particular trial were not possible. It is not known why this occurred. It is suspected, however, that contaminants introduced with different batches of brine shrimp nauplii fed to the fry may have accounted for the irregular mortality patterns.

Only survivors that had been challenged at $1 \mathrm{~d}$ posthatch contained IPNV when tested 3 wk after waterborne virus challenge. Explanations for this finding probably involve the following: the nature of the integument in very young fish and the speed with which effective defense mechanisms develop in these fish. The external integument of newly hatched fry performs exchange functions that are later carried out by the gills and other organ systems (Roberts et al. 1973). It is therefore possible that the immature integument provides a site for attachment and entry of exogenous virus - a site that later becomes inaccessible to virus. In addition to physical changes in the integument, fry may quickly develop other non-specific defense mechanisms (e.g. interferon or cellular defense systems) that may protect them from water-borne microorganisms (Tatner \& Manning 1985). A specific immune response may help protect older fry but this response is probably not a major factor in protecting very young fry (Manning et al. 1982).

Intraperitoneal inoculation of striped bass fingerlings with IPNV resulted in the development of asymptomatic carriers that yielded infectious virus for longer than $1 \mathrm{yr}$. No signs of disease, such as 'spinning' or increased mortalities, were seen in virus-exposed striped bass, even those that were subjected to environmental stress. Although we were unable to induce clinical disease in IPNV-infected striped bass, it seems likely that the virus is capable of replicating in this species (see viral levels in fish, Table 3). It is therefore possible that IPNV might be pathogenic in striped bass fry experiencing several severe concurrent stresses. From the results of our experiments, however, striped bass can be included in the list of non-salmonids that can asymptomatically harbor IPNV (Ahne 1978, Dorson 1982, Bonami et al. 1983, McAllister et al. 1984).

Although the striped bass isolate of IPNV did not prove pathogenic for striped bass in our experiments, it causes clinical disease in brook trout Salvelinus fontinalis (P. E. McAllister unpubl. data). Brook trout are among the salmonid species most susceptible to IPNV (Silim et al. 1982).

Salmonids infected with IPNV usually have histological lesions in the pancreas (McKnight \& Roberts 1976, Swanson \& Gillespie 1979, Swanson et al. 1982, Smail \& Munro 1985). However, no abnormalities were found in any of the IPNV-exposed striped bass we examined. Areas of necrosis were found in the tissues of moribund striped bass fry from which IPNV was isolated (Schutz et al. 1984). However, the etiology of the lesions was not established. In our experiments, we tried to duplicate, as closely as possible, the conditions that existed during the IPNV-associated striped bass mortalities described by Schutz et al. (1984). However, we observed neither clinical nor histological evidence of IPNV-induced disease in our experimental fry.

We did not detect the presence of virus-neutralizing activity in fry or fingerlings following exposure to IPNV in water. However, circulating IPNV-neutralizing antibodies were detected in most virus-inoculated striped bass, even those from which IPNV could be reisolated. We have shown previously that antibody levels develop in striped bass $7 \mathrm{~d}$ after IPNV injection (Wechsler et al. 1986). Salmonid survivors of water challenge with IPNV become virus-carriers with detectable levels of neutralizing antibodies (Yamamoto 1975, Reno et al. 1978).

We demonstrate that although IPNV is not pathogenic in experimentally challenged striped bass these fish can become inapparent virus-carriers. Viruscarriers contaminate their watersheds (Billi \& Wolf 1969) and since IPNV remains infective for months in the aqueous environment (DeSautels \& MacKelvie 1975), carriers can pose a real threat to susceptible species. We suggest, therefore, that all striped bass populations be surveyed for IPNV prior to their introduction into IPNV-free areas. 
Acknowledgements. The funds for this study were provided by the U.S. Fish and Wildlife Striped Bass Emergency Committee, No. 14-16-0009-1544 WO No. 17. The Baltimore Gas and Electric Company generously provided striped bass fry (MD), personnel, use of their facilities, and funds for temporary housing.

\section{LITERATURE CITED}

Ahne, W. (1978). Isolation and characterization of infectious pancreatic necrosis virus from pike (Esox lucius). Arch. Virol. 58: 65-69

Billi, J. L., Wolf, K. (1969). Quantitative comparison of peritoneal washes and feces for detecting infectious pancreatic necrosis virus in carrier brook trout. J. Fish. Res. Bd Can. 26: 1459-1465

Bonami, J. R., Cousserans, F., Weppe, M., Hill, B. J. (1983). Mortalities in hatchery-reared sea bass fry associated with a birnavirus. Bull. Eur. Assoc. Fish Pathologists 3: 41

DeSautels, D., MacKelvie, R. M. (1975). Practical aspects of survival and destruction of infectious pancreatic necrosis virus. J. Fish. Res. Bd Can. 32: 523-531

Dorson, M. (1982). Infectious pancreatic necrosis in salmonids: overview of current problems. In: Anderson, D. P., Dorson, M., DuBourget, P. H. (ed.) Les antigenes des micro-organisms pathogenes des poissons. Collection Foundation Marcel Merieux, Lyon, France, p. 7-32

Luna, L. G. (ed.) (1968). Manual of histological staining methods of the Armed Forces Institute of Pathology, 3rd edn. McGraw-Hill Book Co., New York

Manning, M. J., Grace, M. F., Secombes, C. J. (1982). Developmental aspects of immunity and tolerance in fish. In: Roberts, R. J. (ed.) Microbial diseases of fish. Academic Press, New York, p. 31-46

McAllister, P. E., Newman, M. W., Sauber, J. H., Owens, W. J. (1984). Isolation of infectious pancreatic necrosis virus (serotype $A b$ ) from diverse species of estuarine fish. Helgoländer Meeresunters. 37: 317-328

McKnight, I. J., Roberts, R. J. (1976). The pathology of infectious pancreatic necrosis. I. The sequential histopathology of the naturally occurring conditions. Br. vet. J. 132: 76-84
Reno, P. W., Darley, S, Savan, M. (1978). Infectious pancreatic necrosis: experimental induction of a carrier state in trout. J. Fish. Res. Bd Can. 35: 1451-1456

Roberts, R. J., Bell, M., Young, H. (1973). Studies on the skin of plaice (Pleuronectes platessa) II. The development of larval plaice skin. J. Fish Biol. 5: 103-108

Schutz, M., May, E. B., Kraeuter, J. N., Hetrick, F. M. (1984). Isolation of infectious pancreatic necrosis virus from an epizootic occurring in cultured striped bass, Morone saxatilis. J. Fish Dis. 7: 505-507

Silim, A., Elazhary, A. S. Y., Lagace, A. (1982). Susceptibility of trouts of different species and origins to various isolates of infectious pancreatic necrosis virus. Can. J. Fish. Aquat. Sci. 39: 1580-1584

Smail, D. A., Munro, A. L. S. (1985). Infectious pancreatic necrosis virus persistence in farmed Atlantic salmon (Salmo salar). In: Ellis, A. E. (ed.) Fish and shellfish pathology. Academic Press, New York, p. 277-288

Swanson, R. N., Gillespie, J. H. (1979). Pathogenesis of infectious pancreatic necrosis in Atlantic salmon (Salmo salar). J. Fish. Res. Bd Can. 36: 587-591

Swanson, R. N., Carlisle, J. C., Gillespie, J. H. (1982). Pathogenesis of infectious pancreatic necrosis virus infection in brook trout, Salvelinus fontinalis, following intraperitoneal injection. J. Fish Dis. 5: 449-460

Tatner, M. F., Manning, M. J. (1985). The ontogenic development of the reticulo-endothelial system in rainbow trout, Salmo gairdneri. J. Fish Dis. 8: 189-195

Thompson, S. W (1966). Selected histochemical and histological methods. Charles C. Thomas, Springfield, Massachusetts, p. 24-160

Wechsler, S. J., McAllister, P. E., Hetrick, F. M., Anderson, D.P. (1986). The effect of exogenous corticosteroids on circulating virus and neutralizing antibodies in striped bass (Morone saxatilis) infected with infectious pancreatic necrosis. Vet. Immunol. Immunopath. 12: 305-311

Wolf, K., Sniesko, S. F., Dunbar, C. E., Pyle, E. (1960). Virus nature of IPN in trout. Proc. Soc exp. Biol. Med. 104: 105-108

Yamamoto, T. (1975). Infectious pancreatic necrosis (IPN) virus carriers and antibody production in a population of rainbow trout (Salmo gairdneri). Can. J. Microbiol. 21. $1343-1347$ 